\title{
The case of the Biscayne Bay and aquifer near Miami, Florida: density-driven flow of seawater or gravitationally driven discharge of deep saline groundwater?
}

\author{
K. U. Weyer ${ }^{1}$
}

Received: 28 August 2017 / Accepted: 29 November 2017 / Published online: 21 December 2017

(c) The Author(s) 2017. This article is an open access publication

\begin{abstract}
Coastal groundwater flow investigations at the Cutler site of the Biscayne Bay south of Miami, Florida, gave rise to the dominating concept of density-driven flow of seawater into coastal aquifers indicated as a saltwater wedge. Within that wedge, convection-type return flow of seawater and a dispersion zone were concluded to be the cause of the Biscayne aquifer 'seawater wedge.' This conclusion was merely based on the chloride distribution within the aquifer and on an analytical model concept assuming convection flow within a confined aquifer without taking non-chemical field data into consideration. This concept was later labeled the 'Henry problem,' which any numerical variable-density flow program has to be able to simulate to be considered acceptable. Revisiting the summarizing publication with its record of piezometric field data (heads) showed that the so-called seawater wedge was actually caused by discharging deep saline groundwater driven by regional gravitational groundwater flow systems. Density-driven flow of seawater into the aquifer was not found reflected in the head measurements for low and high tide which had been taken contemporaneously with the chloride measurements. These head measurements had not been included in the assumption of a seawater wedge and associated dispersion zone and convection cell. The Biscayne situation emphasizes the need for any chemical interpretation of flow pattern to be backed up by head data as energy indicators of flow fields. At the Biscayne site density-driven flow of seawater did not and does not exist. This conclusion was confirmed by five independent methods. The hydrostatic use of vertical buoyancy forces needs, under hydrodynamic boundary conditions, to be replaced with buoyancy forces along the direction of the pressure potential forces [(grad p)/density] which, in the subsurface, can be pointed in any direction in space.
\end{abstract}

Keywords Biscayne Bay $\cdot$ Coastal aquifers $\cdot$ Density-driven flow $\cdot$ Regional groundwater flow systems $\cdot$ Henry problem

\section{Introduction}

In the 1950s and 1960s, the USGS investigated the role of seawater in the flow pattern of the Biscayne aquifer near Miami, Florida (Fig. 1), by measuring heads and chemistry in piezometer nests. Most of the essential data were collected, and their interpretations were published by Cooper et al. (1964). These authors also had published individual papers previously dealing with their part of these investigations as Cooper (1959), Glover (1959), Henry (1959, 1960a, b, 1962, 1964) and Kohout (1960a, b). All the above

K. U. Weyer

weyer@wda-consultants.com

1 WDA Consultants Inc., 4827 Vienna Drive NW, Calgary, AB T3A0W7, Canada publications had a lasting impact on the way seawater intrusion was considered worldwide thereafter. The concept of wedge-shaped intrusion of saltwater under the freshwater of a coastal aquifer has been carried through much of the literature as well as the assumption of the occurrence of convection cells within the saltwater wedge, and the associated occurrence of dispersion as stated by Cooper et al. (1964).

A selection of text books and handbooks spreading this concept includes Bear (2007a, Fig. 9-37, 2007b, Fig. 12.4), De Wiest (1965, Figs. 7-10, 7-11), Domenico (1972, Fig. 4.22), Fetter (1994, Fig. 9.34), Freeze and Cherry (1979, p. 378), Pinder and Celia (2006, Fig. 1.27), Schwartz and Zhang (2004, Fig. 8.34), Todd and Mays (2005, Fig. 14.4.1), and Walton (1970, Figs. 3.27, 3.28). All these books refer to the field work and the related data interpretation summarized by Cooper et al. (1964). Thus, the concepts contained in Cooper et al. (1964) have been widely adopted as a base for 


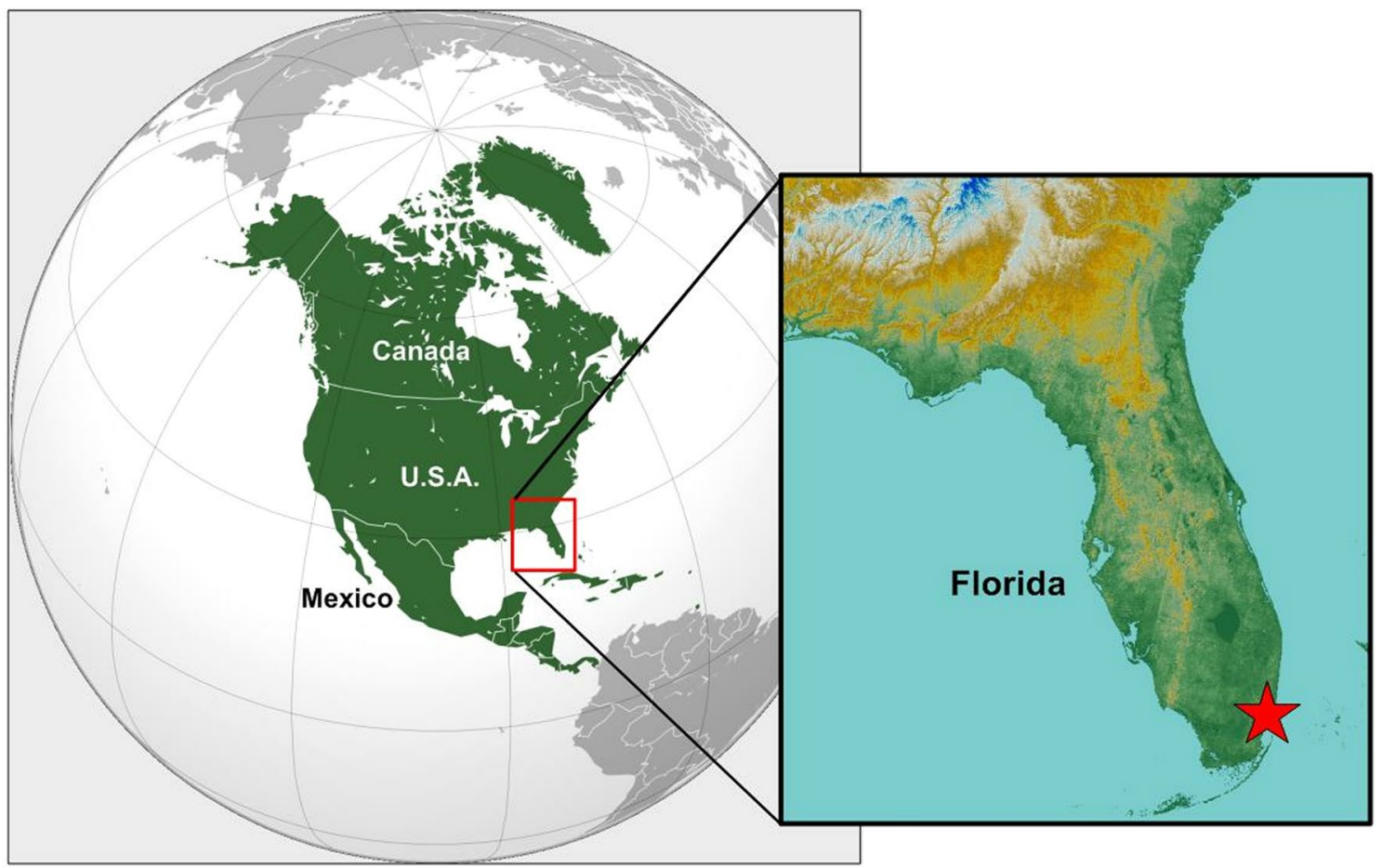

Fig. 1 Location of Cutler site study area at Biscayne Bay and aquifer near Miami, Florida (red star). Map of North America modified after Wikipedia (creator: Bosonic dressing, 2009). For more detail, see Fig. 13. DEM by WDA Consultants Inc., 2016. Data derived from NASA's Shuttle Radar Topography Mission (SRTM) dataset, extracted by the program GlobalMapper into a 764-m grid dealing with seawater intrusion and flow with contrasting density in coastal aquifers.

The postulated coastal saltwater wedge as the mechanism of saltwater intrusion in coastal aquifers by density-driven flow was also adopted into scientific literature and numerical modeling, as, for example, by Pinder and Cooper (1970, Figs. 3, 4 and 5), Lee and Cheng (1974, Figs. 3, 4 and 5), Segol and Pinder (1976), and Bear and Bachmat (1990, Fig. 8.41). Further examples for equal isochlor line calculation of salt wedges include the program SUTRA (Voss and Provost 2010, p. 169), as well as such journal articles as $\mathrm{Lu}$ et al. (2015, Fig. 1).

Langevin (2001) and Guo and Langevin (2002) explicitly developed the variable-density flow program system SEAWAT (a combined version of MODFLOW and MT3D) to deal with the simulation of complex variable-density groundwater flow pattern at Biscayne Bay. Langevin (2001) and Guo and Langevin (2002) verified the code SEAWAT 'by running four different problems and comparing the results to those from other variable-density codes.' These benchmark problems were (1) the Box problems (described in: Voss and Souza 1987), (2) the Henry problem (described in: Voss and Souza 1987), (3) the Elder Problem (described in Voss and Souza 1987) and (4) HYROCOIN (Hydrologic Code Intercomparison project) Problem \#5 (described in: Konikow et al. 1997). The verification process did not include the Salt Lake problem (described in Simmons et al. 1999). Figure 2 depicts the concepts used for numerical modeling of coastal ground and seawater flow based on the interpretation of the Cutler site.

The concept of saltwater wedges and density-driven groundwater flow in coastal aquifers has since been applied to the coastal interaction of freshwater and seawater (Feseker 2007; Langevin and Zygnerski 2013; Merritt 1996; Shoemaker 2004; Werner and Simmons 2009; Werner et al. 2012.), water supply from coastal aquifers in Florida and elsewhere (Anderson et al. 1988; Rao et al. 2004; Spechler 1994), as well in the prediction of the effects of sea level rise in these aquifers (Masterson 2004; Masterson and Garabedian 2007; Rozell and Wong 2010).

As the saltwater wedge mechanism with its dispersion zone contradicts coastal flow patterns derived from numerical models which are built on gravitationally driven force potentials (Hubbert 1940, 1953; Tóth 1963; Freeze and Witherspoon 1967), the historical literature was revisited. The objective of this paper is to report the results of this review after first outlining the physical differences between 'density-driven flow' and gravitationally driven 'groundwater flow systems.' During this review, five independent methods will be used to prove that the saltwater wedge in the Biscayne aquifer has not been created by seawater intrusion, as assumed by Cooper et al. (1964), 


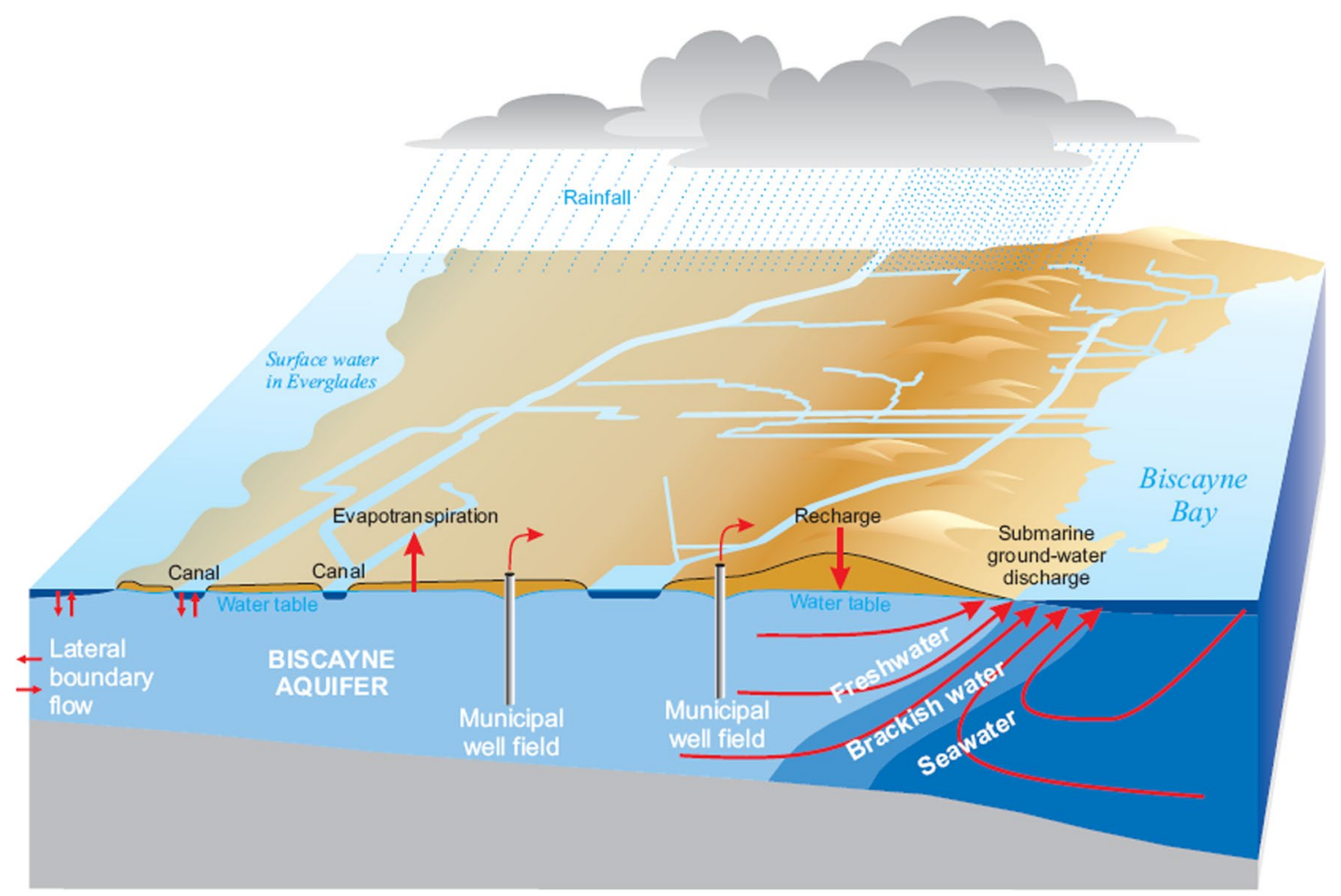

Fig. 2 Conceptual hydrologic model used to develop numerical models of variable-density groundwater flow at Biscayne Bay showing postulated seawater wedge, zone of dispersion and convection cell (from Langevin 2001, Fig. 15). Note Figures originating from USGS

but by the discharge of regional groundwater flow systems, delivering saline groundwater from depth

- the physics of 'density-driven flow' versus 'groundwater flow systems,'

- the occurrence of artesian (flowing) deep wells throughout South Florida,

- the penetration depth of fresh groundwater to $600 \mathrm{~m}$ and more indicated by chemical data,

- the occurrence of the freshwater/saltwater boundary in oil well P115 at approximately $1800 \mathrm{ft}(600 \mathrm{~m})$ about 10 miles $(15 \mathrm{~km})$ west of Biscayne Bay (Williams and Kuniansky (2016, plate 19),

- the equal head lines of the equivalent freshwater heads as presented by Cooper et al. (1964) (Fig. 16 and 17).

\section{Physics of density-driven flow and gravitational groundwater flow systems}

Modern literature creates the impression that there is a fundamental difference in the physics of density-driven flow and that of groundwater flow systems. It is clear, however, that both 'modes' of flow are driven by gravitational forces. publications have not been modified to maintain their original composition. These papers can be downloaded for free from USGS websites. Their URLs are listed in the list of references

Thus, the question arises where the difference between the two modes lies. Unexpectedly the solution is relative simple: the difference lies in the boundary conditions; density-driven flow occurs under hydrostatic boundary conditions (Fig. 3, left side), while groundwater flow systems occur on land and under coastal areas under hydrodynamic conditions (Fig. 3, right side).

Under hydrostatic conditions, no flow occurs within equal-density fluids. The vectors for the resultant calculation are of the same magnitude with opposite vertical directions. Introducing an additional fluid of higher or lower density than the host fluid creates an upward or downward movement of the introduced fluid in dependence of its density as determined by simple resultant calculations (Fig. 4, left side). The created force is habitually called a 'buoyancy force' and is applied in strictly vertical directions: upwards or downwards. That is done not only under hydrostatic conditions but, erroneously, also under hydrodynamic conditions. Hydrostatic conditions (Fig. 4, left side) are a special case of hydrodynamic conditions (Fig. 4, right side).

Under hydrodynamic conditions, the pressure potential vector $[-(\operatorname{grad} \mathrm{p}) / \rho]$ can occur in any direction in space (including vertically upwards and downwards), but then its magnitude is different from that of the gravitational vector 


\section{hydrostatic \\ "density-driven flow"}

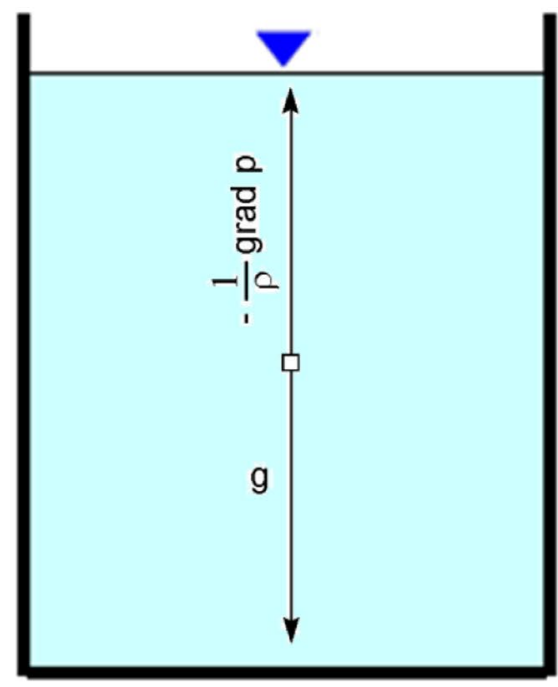

hydrodynamic

"groundwater flow systems"

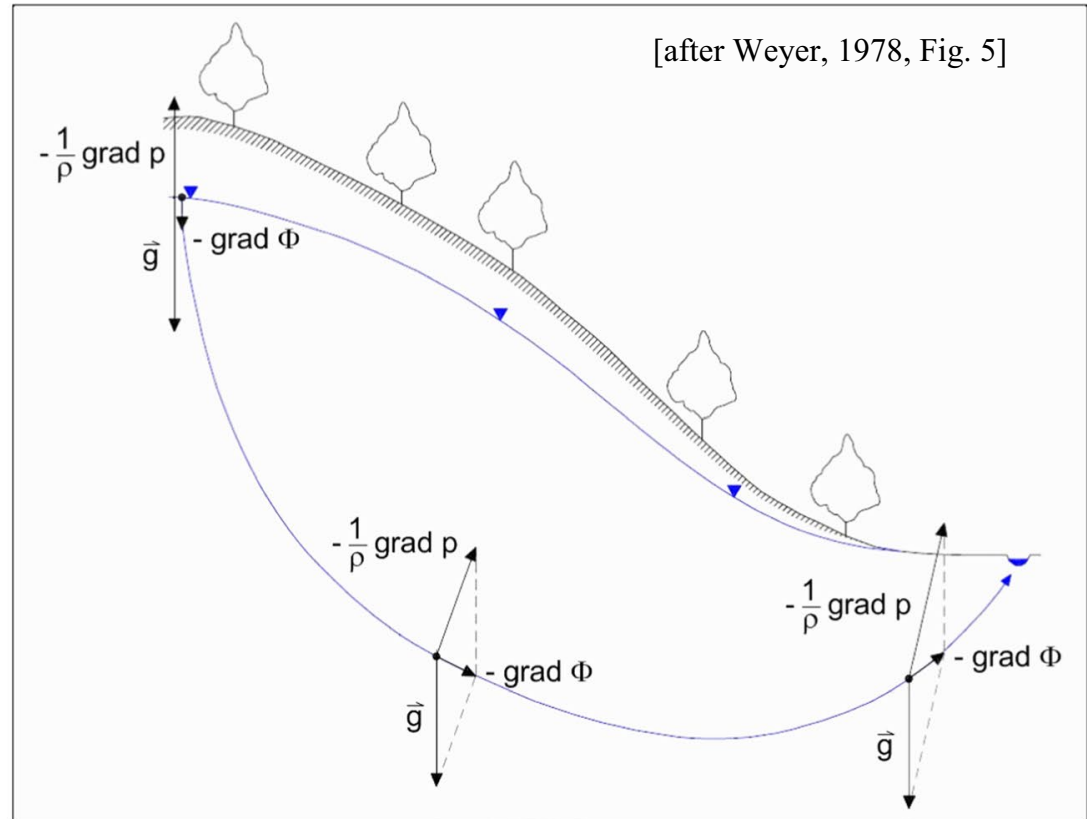

Fig. 3 'Density-driven flow' under hydrostatic conditions versus gravitationally driven 'groundwater flow systems' under hydrodynamic conditions. From Weyer (2017b, after Weyer 1978)
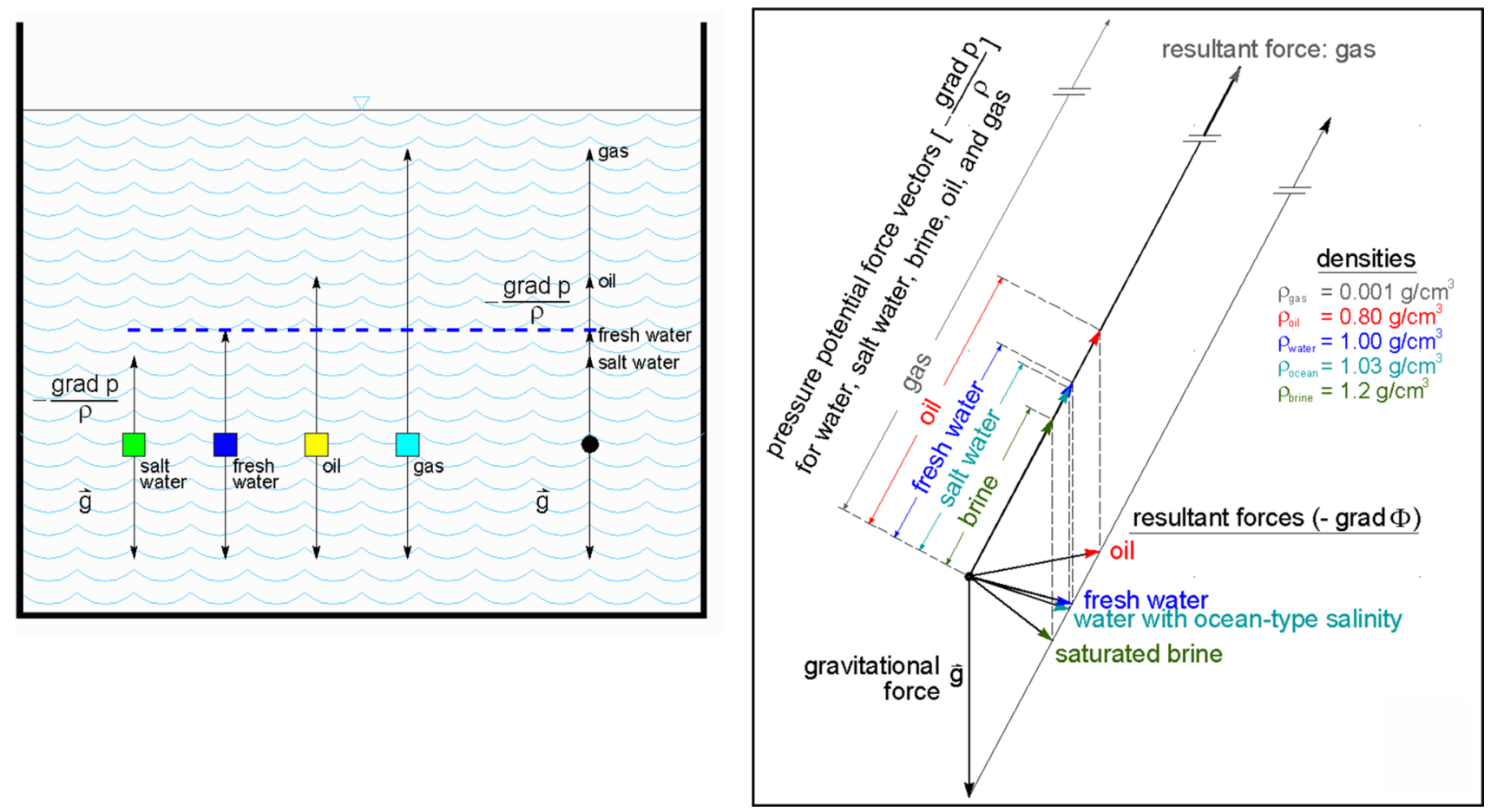

Fig. 4 Force vector calculation for density-driven flow under hydrostatic conditions versus gravitationally driven 'groundwater flow systems' under hydrodynamic conditions. After Weyer (2010, 2017b) 
g. Figure 4 (right side) visualizes schematically that under hydrodynamic conditions the resultant calculation for variable-density flow returns differing flow directions for the fluids of contrasting density. The vectors of the force fields are shown here in the force potential notation (Hubbert 1940). Hubbert (1953, p. 1982, Fig. 16 and accompanying text) shows that the density effects ('buoyancy forces') are added in the direction of the pressure potential gradient of the host fluid (freshwater) even in areas without freshwater (Hubbert 1953, p. 1960). Hence, the habitual addition of the assumed vertical 'buoyancy forces' to head forces is arbitrary and contradicts the laws of physics.

Here a paradigm shift occurs which contradicts the principles of 'density-driven flow' in any system with hydrodynamic boundary conditions in two respects (1) mixing of hydrodynamic with hydrostatic conditions and (2) application of velocity potential (energy/unit volume; assumption: incompressible fluid) instead of force potentials (energy/unit mass; compressible fluids).

This section outlined the physics involved in the problem addressed by this paper. In the following, the attention is first directed toward the general geology and lithology of Florida and subsequently to the field work undertaken by Cooper at al. (1964) and the interpretation of the field data obtained.

\section{General tertiary and uppermost cretaceous geology and lithology of Florida}

From a hydrodynamic point of view, the geology and lithology of Florida are dominated by sand layers at the surface and carbonates and minor sandstone layers at greater depth. These types of fractured and often karstic rocks facilitate the formation of far-reaching regional groundwater flow systems even at the moderate elevation differences of less than $100 \mathrm{~m}$ between recharge and discharge areas.

The Tertiary (Paleocene) carbonates are part of the Upper Floridan and Lower Floridan Aquifer systems overlain, separated, and underlain by confining layers (Fig. 5). The Cedar Keys Formation forms the lower confining unit and is located above the uppermost Cretaceous layer, the Lawson Formation of carbonate lithology.

\section{Interpretation of chemical field data for flow of freshwater and saltwater in the Biscayne aquifer}

The distribution of the isochlor lines in Fig. 6 creates the optical impression that seawater is flowing at the bottom of the Biscayne aquifer away from Biscayne Bay. Such is the explicit explanation which was given by the USGS (Miller 1990, Fig. 39) as shown in Fig. 7. The same interpretation has been adopted by all text books quoted in the introduction above.

Schwartz and Zhang (2004) incorporated Miller's (1990) Fig. 39 as their Fig. 8.34. This data interpretation fits well into the widely spread opinion that chemical data and isotope data are adequate to determine flow direction within groundwater flow systems. This paper will show that interpretations based solely on chemistry may be prone to unfounded conclusions. Chemical and isotope investigations should always be supported by head measurements of groundwater flow systems taking density variations into account.

Admittedly, the equal isochlor lines in Fig. 6 lent themselves to the quick interpretation of hydrodynamical flow pattern as shown in Fig. 7.

\section{Interpretation of head data for flow of freshwater and saltwater in the Biscayne aquifer}

While Cooper (1959), Glover (1959), Henry (1959, 1960a, b, 1962) and Kohout (1960a, b) only show a selection of field data, Cooper et al. (1964) reported hydraulic field data as equivalent freshwater heads. They indicate the general flow directions of freshwater and saltwater in the Biscayne aquifer, close to and under parts of Biscayne Bay. Kohout (1964, p. C28) interprets the associated flow directions in his Figs. 15-17 as follows:

The equipotential lines in the upper, freshwater part of the aquifer indicate the potential of freshwater in a freshwater environment and hence indicate comparative potentials. As flow lines must be nearly perpendicular to these equipotential lines, a seaward movement of freshwater is indicated.

In the lower and seaward part of the aquifer, the equipotential lines indicate the potential of freshwater in a 
Fig. 5 Hydrogeologic framework of the Floridian aquifer system, depth of freshwater regional groundwater flow system as indicated by the boundary between flowing freshwater and static saltwater (after Bush and Johnson 1986, Fig. 9). The figure text here has been redone, and the interface between the freshwater and saltwater highlighted in red to improve clarity

\section{GEOLOGIC UNITS IN HYDROGEOLOGICAL FRAMEWORK}
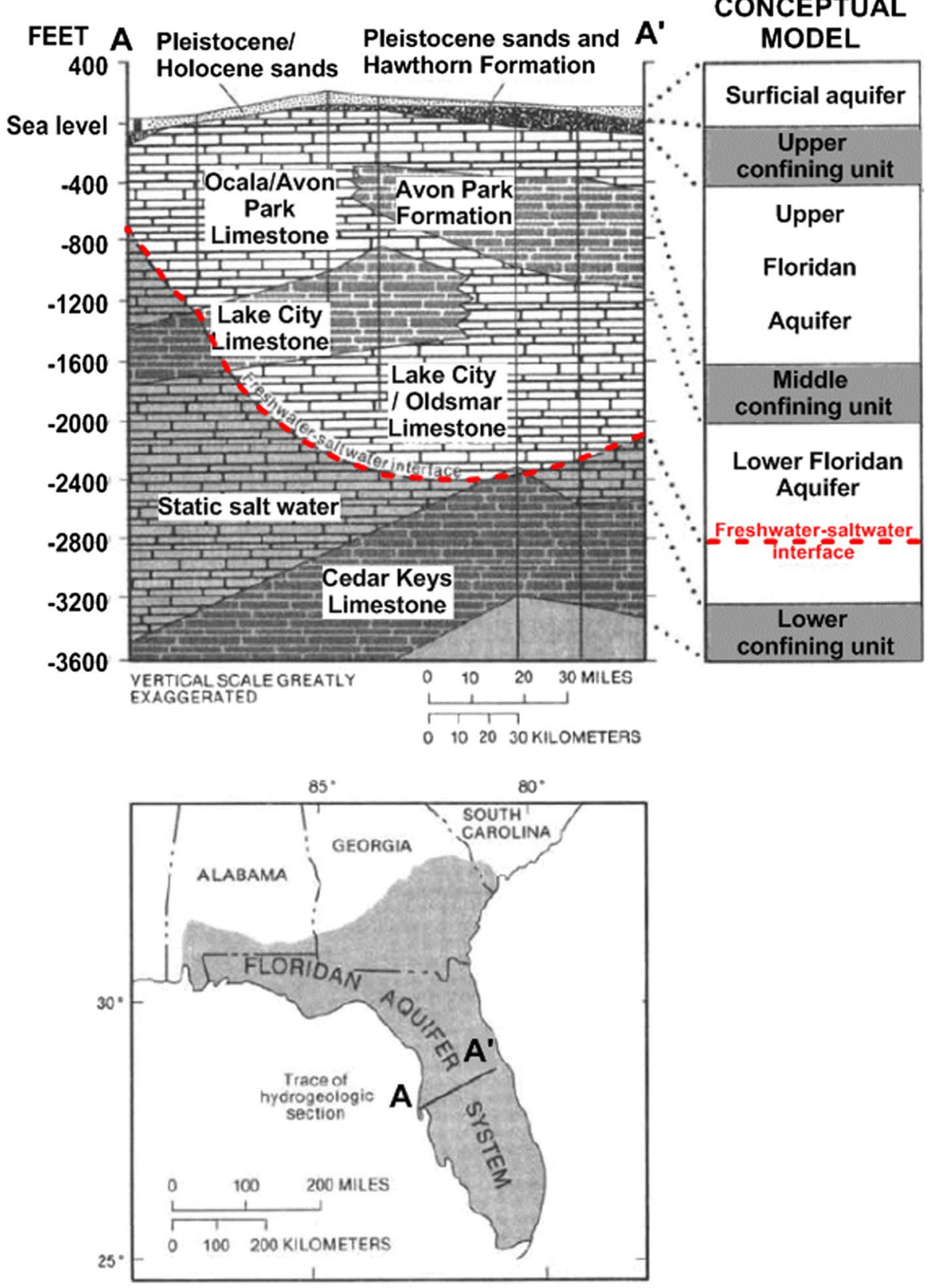

HYDROGEOLOGIC UNITS IN CONCEPTUAL MODEL region occupied by saltwater. The freshwater equipotential surfaces in a region occupied by saltwater will be horizontal if the saltwater is static. As the equipotential lines in the saltwater regions of Figs. 15 to 17 are not horizontal but slope inland in Fig. 15, seaward in Fig. 16, and inland in Fig. 17, the saltwater is not static but must be in motion in the direction of the slope. [emphasis added]
Kohout's (1964) Fig. 16 has been reproduced here as Fig. 8. As Kohout (1964, pages C12-C35 in Cooper et al. 1964) himself clearly stated above that 'flow lines must be nearly perpendicular to these equipotential lines,' it is difficult to grasp why he then concludes above that 'the salt water must be in motion in the direction of the slope' of the equipotential lines which to him implied lateral flow of seawater into the Biscayne aquifer. 


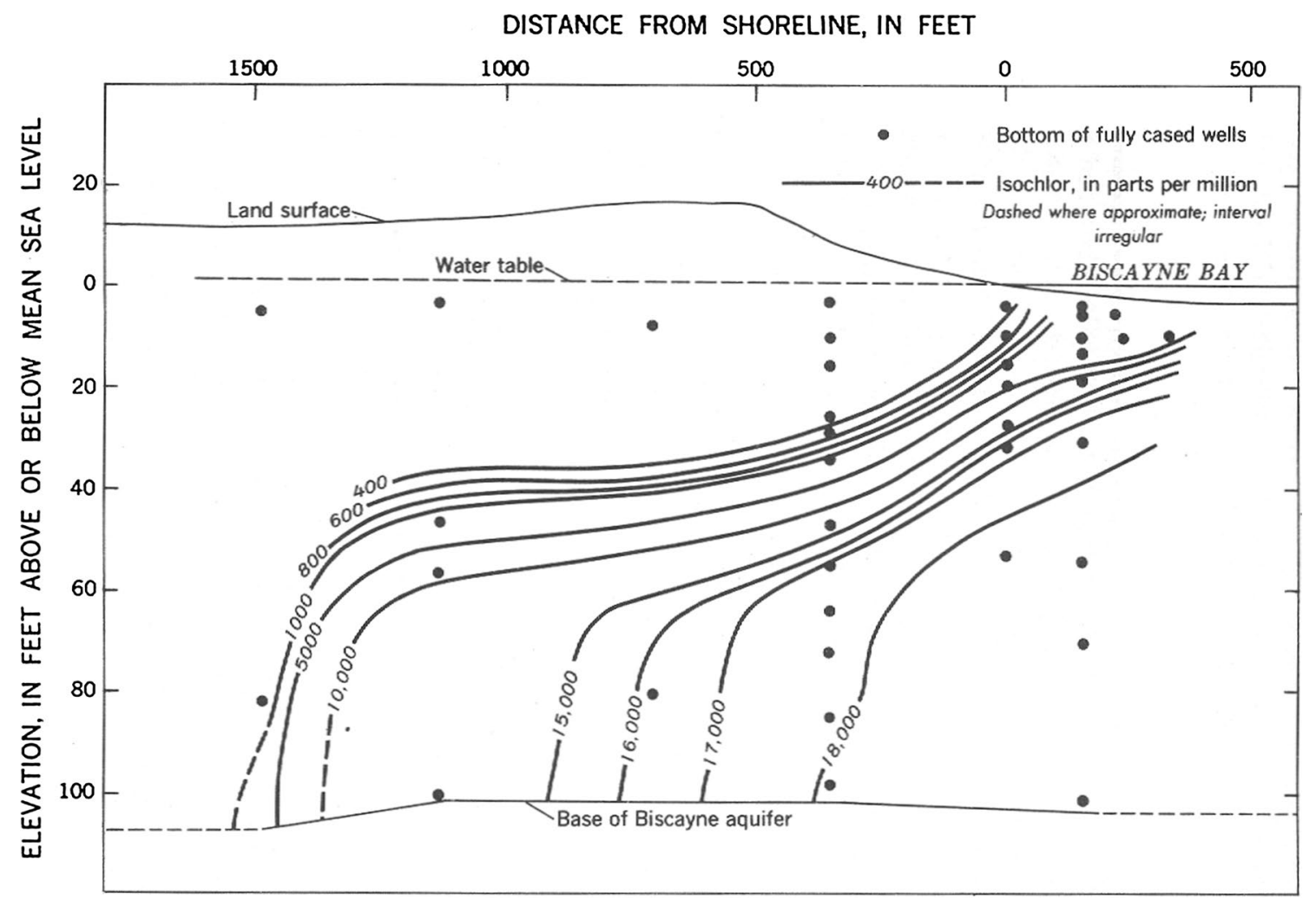

Fig. 6 Section through the Cutler area near Miami, showing chemical sampling points and isochlor lines in ppm within the Biscayne aquifer for September 8, 1958 (from Cooper et al. 1964, Fig. 5)

Figure 39. Saltwater extends farther inland near the base of the Biscayne aquifer rather than near the top of it.

\section{EXPLANATION}

--.500- Line of equal chloride concentration-Dashed where approximately located. Interval, in milligrams per liter, is variable

Direction of ground-water movement

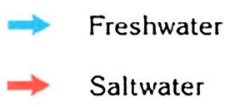

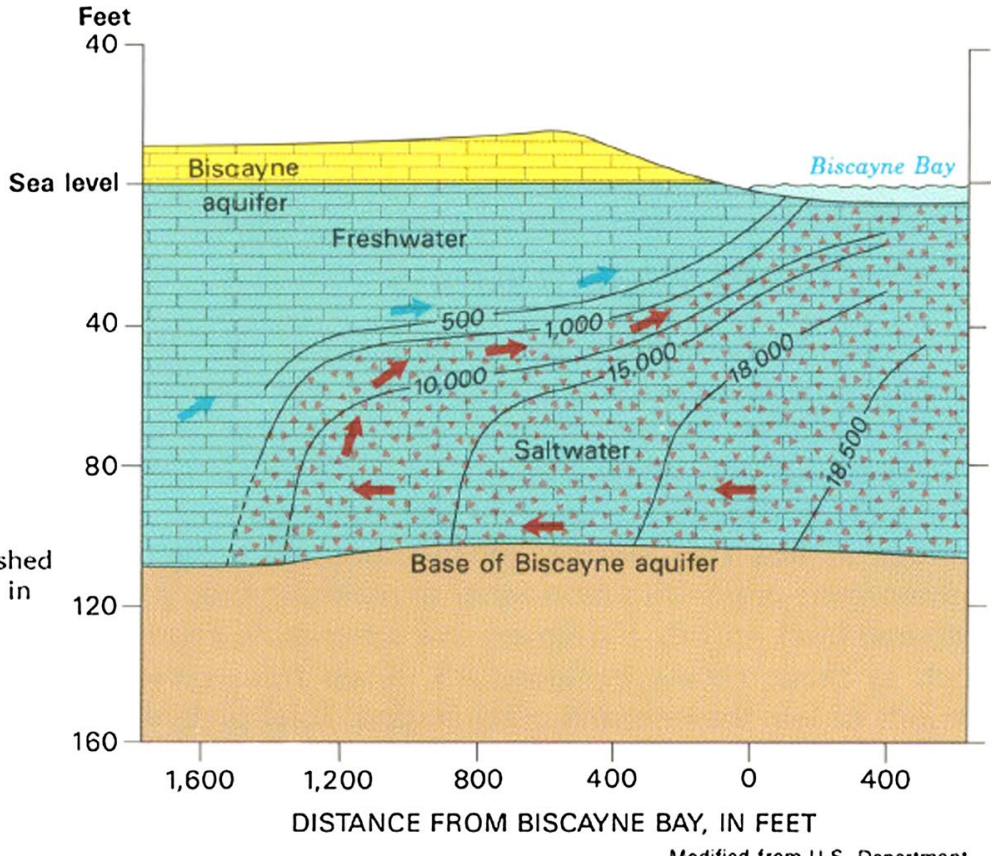

Modified from U.S. Department of the Interior, 1973

Fig. 7 Widely accepted interpretation of chemical data for freshwater and seawater flow in the Cutler section near Miami within the Biscayne aquifer (from Miller 1990, Fig. 39) 
It is even more perplexing as Kohout (1964) stated on page $\mathrm{C} 23$ :

Where the density varies from point to point, measurements of head do not indicate the direction of movement directly. For this reason the observed saltwater heads in the wells have been converted to freshwater heads by computation.

The point of computing equivalent freshwater heads is that they are supposedly suited to determine the flow directions of freshwater and saltwater alike, or at least the general trend of the flow pattern. Accordingly, the approximate flow directions within the saltwater portion of Figs. 8 and 9 were inserted by hand.

The inserted flow lines are perpendicular to lines of equal equivalent freshwater heads as they should be according to above statements by Kohout himself. It is therefore clear that this is not a saltwater wedge created by flow of seawater from Biscayne Bay. Instead the saltwater has been transmitted by discharging saline regional groundwater flow systems from the Cedar Keys Formation. Stringfield (1966, p. 36) reported for the Cedar Keys Formation chloride concentration of up to 23,000 and of $53,000 \mathrm{ppm}$ in the underlying Lawson Formation.

Figure 10 documents how Kohout (1964, in Cooper et al. 1964) adopts the interpretation of the encountered flow pattern, clearly supporting the postulates of density-driven flow, diffusion and dispersion as well as convection flow at this location. This interpretation then promoted the acceptance of the occurrence of seawater wedges in coastal aquifers worldwide.

Henry's (1964) simulation of seawater flow from Biscayne Bay into the Biscayne aquifer (Fig. 11) reflected neither the head measurements nor the interpretation based on equal isochlor lines (compare Figs. 6, and 7). In the field, the conditions were unconfined and not confined as assumed

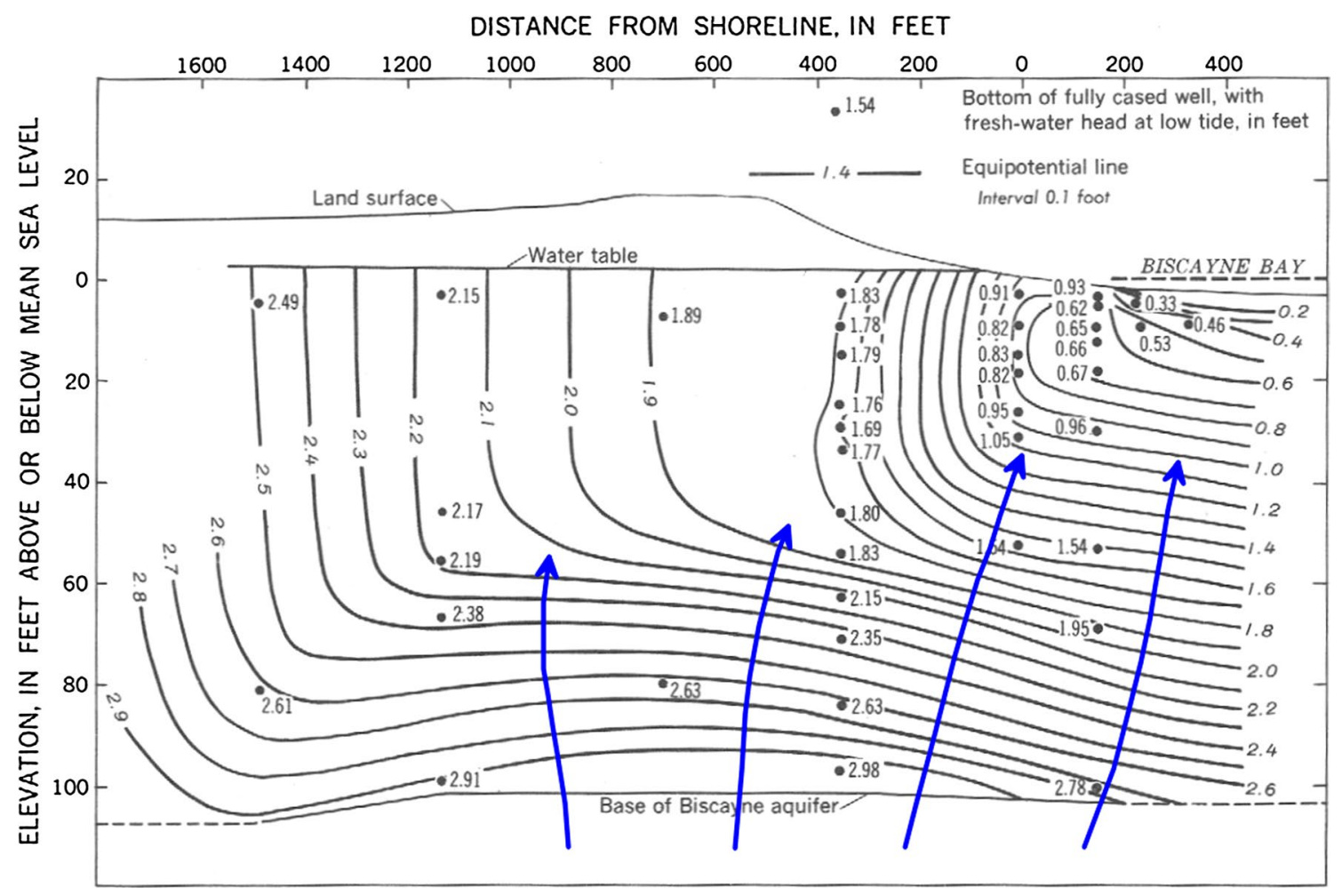

Fig. 8 Cross section through the Cutler area, near Miami, Fla., showing lines of equal freshwater heads at 0750 (bay low tide) September 18, 1958 (From Cooper et al. 1964, Fig. 16). Blue flow arrows added showing upward flow of deep seated groundwater flow systems carrying salt from the Paleocene Cedar Keys formation 


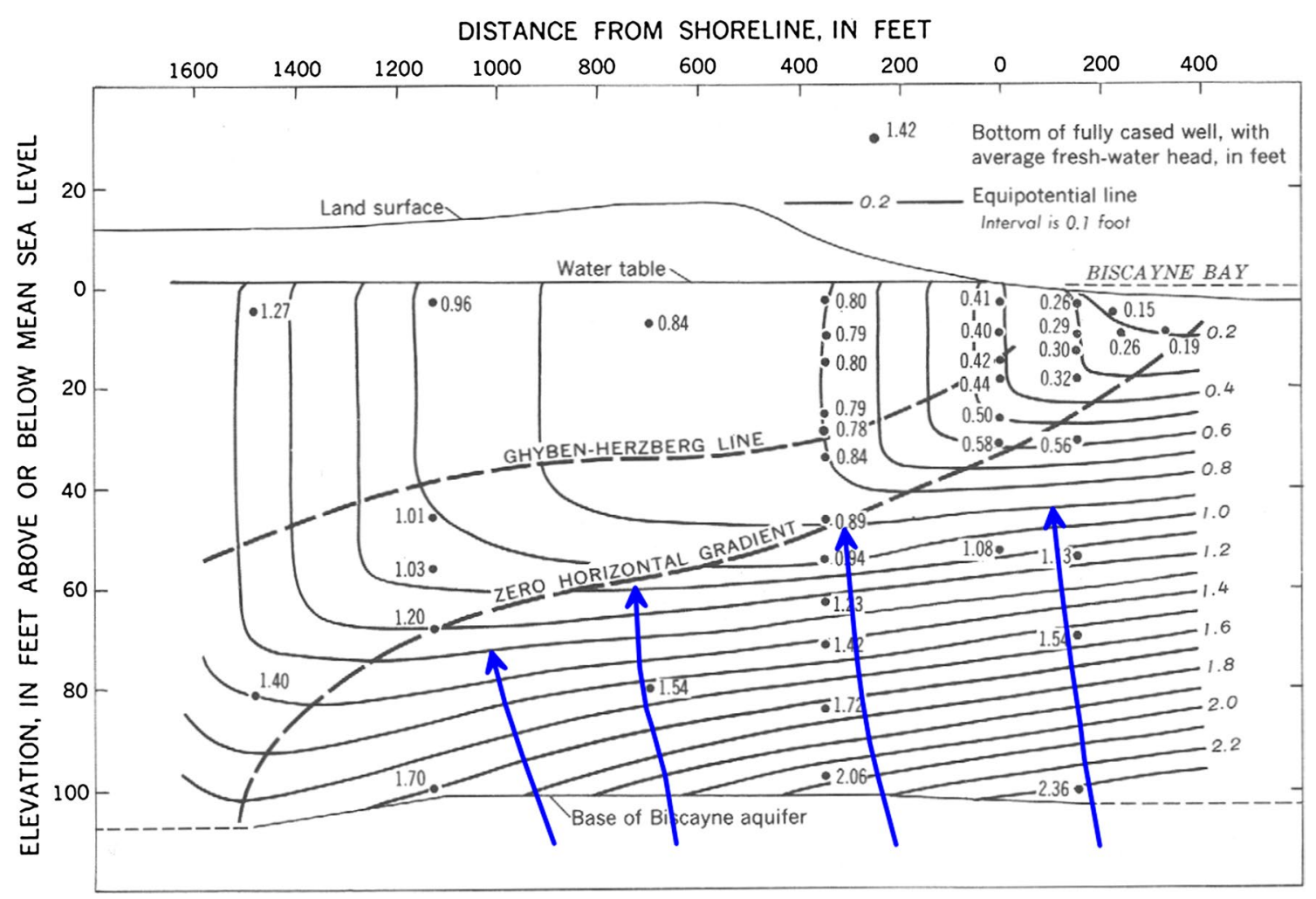

Fig. 9 Cross section through the Cutler area, near Miami, Fla., showing lines of equal freshwater heads for a low-head condition average for September 18, 1958 (from Cooper et al. 1964, Fig. 17). Blue flow

in Henry's simulation. One could suspect that Henry (1964) needed to assume confined conditions in order to accommodate an analytical mathematical solution. From then on this limitation has determined the procedures used worldwide to simulate saltwater intrusion.

Figure 11 taken from Henry (1964, Fig. 34), however, forms the blueprint for solving the Henry problem. Voss and Provost (2010, p. 169) state as 'Physical Setup' for 'Density dependant flow and solute transport (Henry 1964) solution for seawater intrusion' as follows:

This problem involves seawater intrusion into a confined aquifer studied in cross section under steady conditions. Freshwater recharge inland flows over saltwater in the section and discharges at a vertical sea boundary.

The intrusion problem is nonlinear and may be solved by approaching the steady state gradually with a series of time steps. Initially there is no saltwater in the aquifer, and at time zero, saltwater begins to intrude the freshwater system by moving under the freshwater arrows added showing upward flow of deep seated groundwater flow systems carrying salt from the Paleocene Cedar Keys formation

from the sea boundary. The intrusion is caused by the greater density of the saltwater.

Dimensions of the problem are selected to make for simple comparison with the steady-state dimensionless solution of Henry (1964), and with a number of other published simulation models. A total simulation time of $t=100.0$ [min], is selected, which is sufficient time for the problem to essentially reach steady state at the scale simulated.

The simulated flow patterns do not do justice to the actual flow and head patterns measured by Kohout (1964) at the site for which the Henry problem had been developed. The pattern measured can only be explained by the pattern of gravity-driven regional groundwater flow systems prevailing in central and south Florida. H.H. Cooper Jr, the main author in Cooper and al. (1964) and the coauthor of the paper by Pinder and Cooper (1970), was actively involved in developing the salt wedge concept reported by Kohout (1964). 


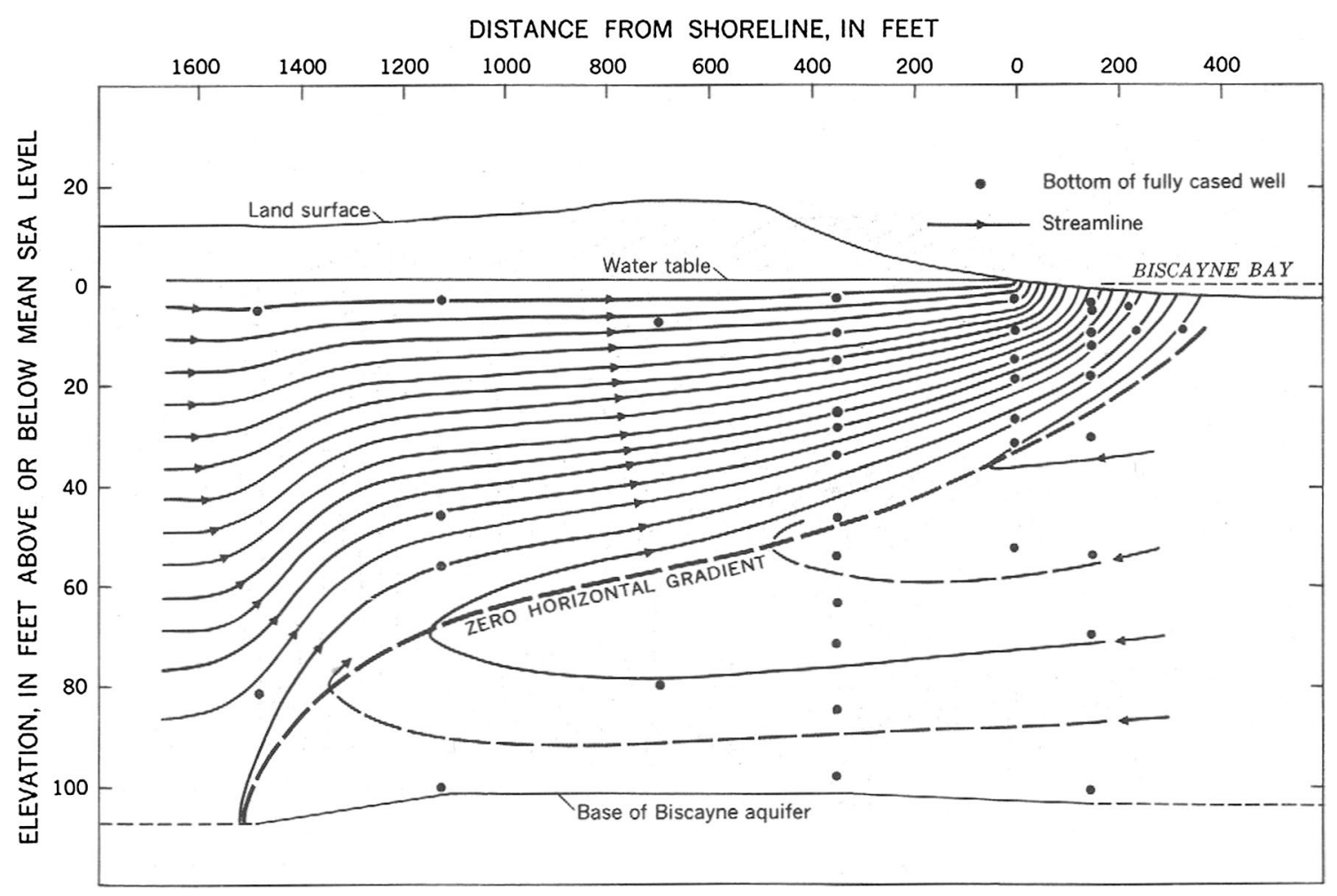

Fig. 10 Cross section through the Cutler area, near Miami, Fla., showing the postulated pattern of flow of fresh and saltwater for a low-head condition, September 18, 1958 (from Cooper et al. 1964, Fig. 19)

\section{Manifestation of deep regional flow systems in Florida}

It has been shown above that the equal isochlor lines at the Cutler area near Miami have been caused by upward discharge of fresh and saline deep groundwater as well as lateral discharge of shallower fresh groundwater. While it is not difficult to locate nearby recharge areas for more local groundwater flow systems, as defined by Tóth (1963), the question arises where the deep regional part of the groundwater flow systems recharges. This paper owes the answer to the work by Healy (1962a, b) and the summary description by Stringfield (1966). The recharge areas for the deep groundwater flow systems in South Florida are the Central Highlands from which the regional groundwater flow systems migrate to the eastern and western Coastal Low Lands as well as to South Florida (see Fig. 12). Due to the energy needed for upward discharge against gravitational forces, discharge areas are always characterized by artesian (flowing) wells. Stringfield (1966, Fig. 29) indicated the artesian heads in the Floridian aquifer to be at about 6 mamsl $(20 \mathrm{ft}$ amsl) elevation at the coast of the Biscayne Bay and about 16 mamsl (50 ft amsl) at Lake Okeechobee.

The penetration depth of the flow system is indicated in Fig. 5 along a cross section in Central Florida to be about $800 \mathrm{~m}$ ( $2400 \mathrm{ft})$. Recharge areas in the Central Highlands reach elevations exceeding 70 mamsl. These elevations suffice to maintain, within the Floridian aquifer system, regional flow systems to the coasts at the Atlantic, south Florida and the Gulf of Mexico. It is not quite clear which definition of freshwater had been used by Bush and Johnson (1986). In any case, however, the boundary given between fresh and saltwater reliably indicates the general penetration depth of groundwater flow under the recharge area. About 10 miles west of Biscayne Bay, Williams and Kuniansky (2016, plate 19) report in oil well P115 the freshwater-saltwater boundary at an approximate depth of $1800 \mathrm{ft}(\sim 600 \mathrm{~m})$ with an TDS concentration of approximately 10,000 mg/l. This indicates that the regional groundwater discharge of saline water at Biscayne Bay migrated upwards from a depth of about $600 \mathrm{~m}$ or more. This explains the salt concentrations reported as equal isochlor lines in Fig. 6. The isochlor lines have not been created by seawater flow from Biscayne 
Fig. 11 Flow and salt concentration patterns in an idealized mathematical model. Model calculated by Henry (1964) in Cooper et al. (1964), Fig. 34, known as the 'Henry problem' which new variable-density flow computer programs must meet to be considered functional
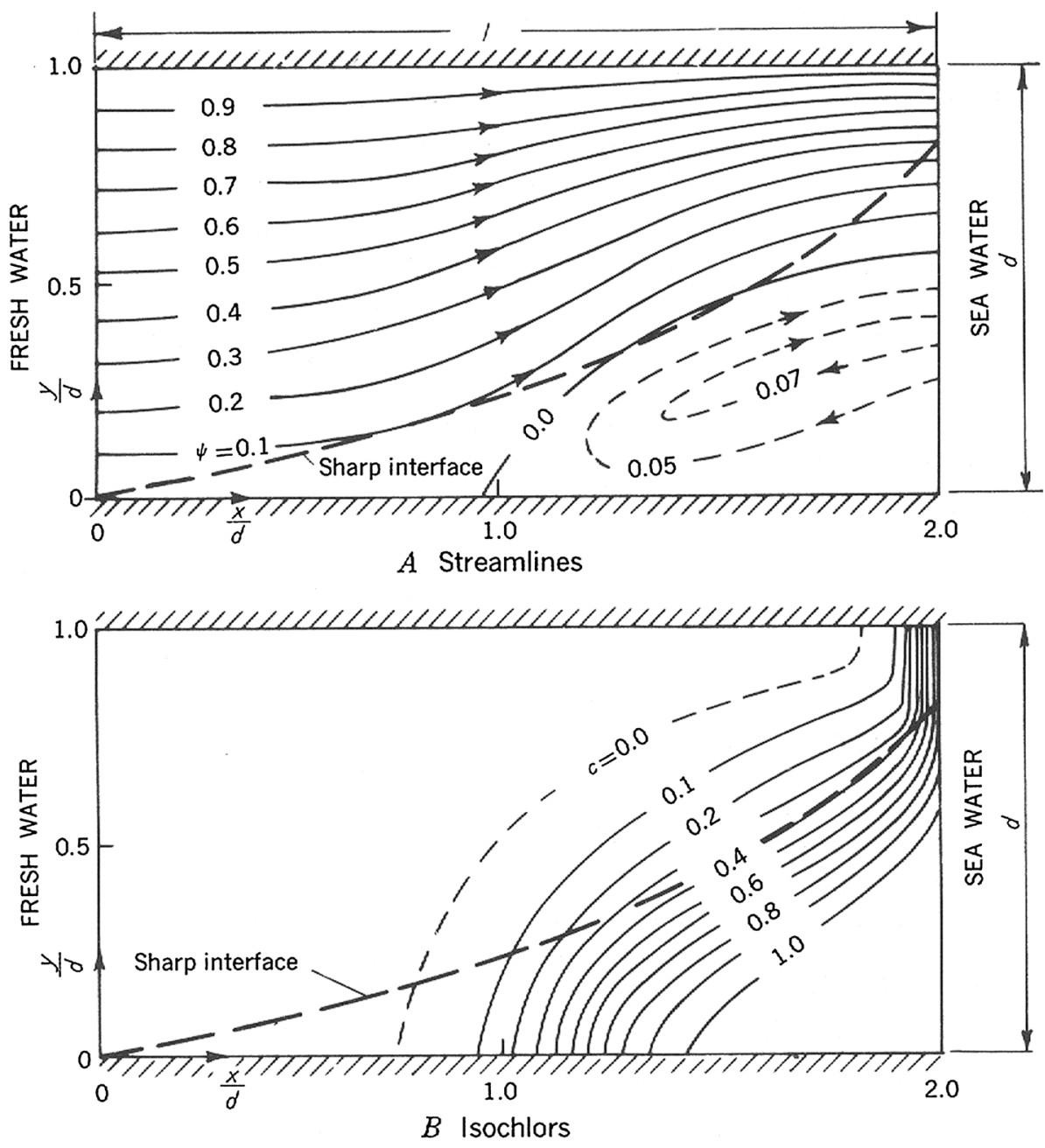

Bay and the action of a zone of dispersion as postulated by Kohout (1964) in Cooper et al. (1964). This dispersion zone and the postulated coastal convection flow zone did and do not exist.

The salt wedge interpretation forwarded by Kohout (1964, in Cooper et al. 1964) constitutes a severe misunderstanding and misinterpretation of field data, and in view of the importance for coastal water supply, the new understanding needs to be included in numerical modeling and proper practical water supply management world-wide.

An outline of the deep groundwater flow system leading from the Central Florida Uplands to Biscayne Bay is shown schematically in Fig. 13 (topographic trace of cross section) and in Fig. 14 (cross section schematically showing regional and local groundwater flow systems).

\section{Conclusions}

In an attempt to explain the pattern of equal isochlor lines at a test site for saltwater intrusion at Biscayne Bay near Miami (Cooper et al. 1964), groundwater flow pattern was derived from chemical data and an analytical model calculation and taken as proof for the invasion of seawater into the Biscayne aquifer. Contemporaneously measured head data were in stark contrast to this conclusion. The application of this procedure and its conclusions may be understandable as in the 1950s and early 1960s the role of aquitards was not yet fully recognized as efficient transmitters of groundwater flow and the classical papers on groundwater flow systems had not been published yet.

That may be one reason why the influence of the publications by Cooper (1959), Kohout (1960a, b) and Henry (1959, 1960a, b, 1962) and Cooper et al. (1964) dominated the conceptual understanding of seawater intrusion and its numerical analysis under conceptually assumed boundary 


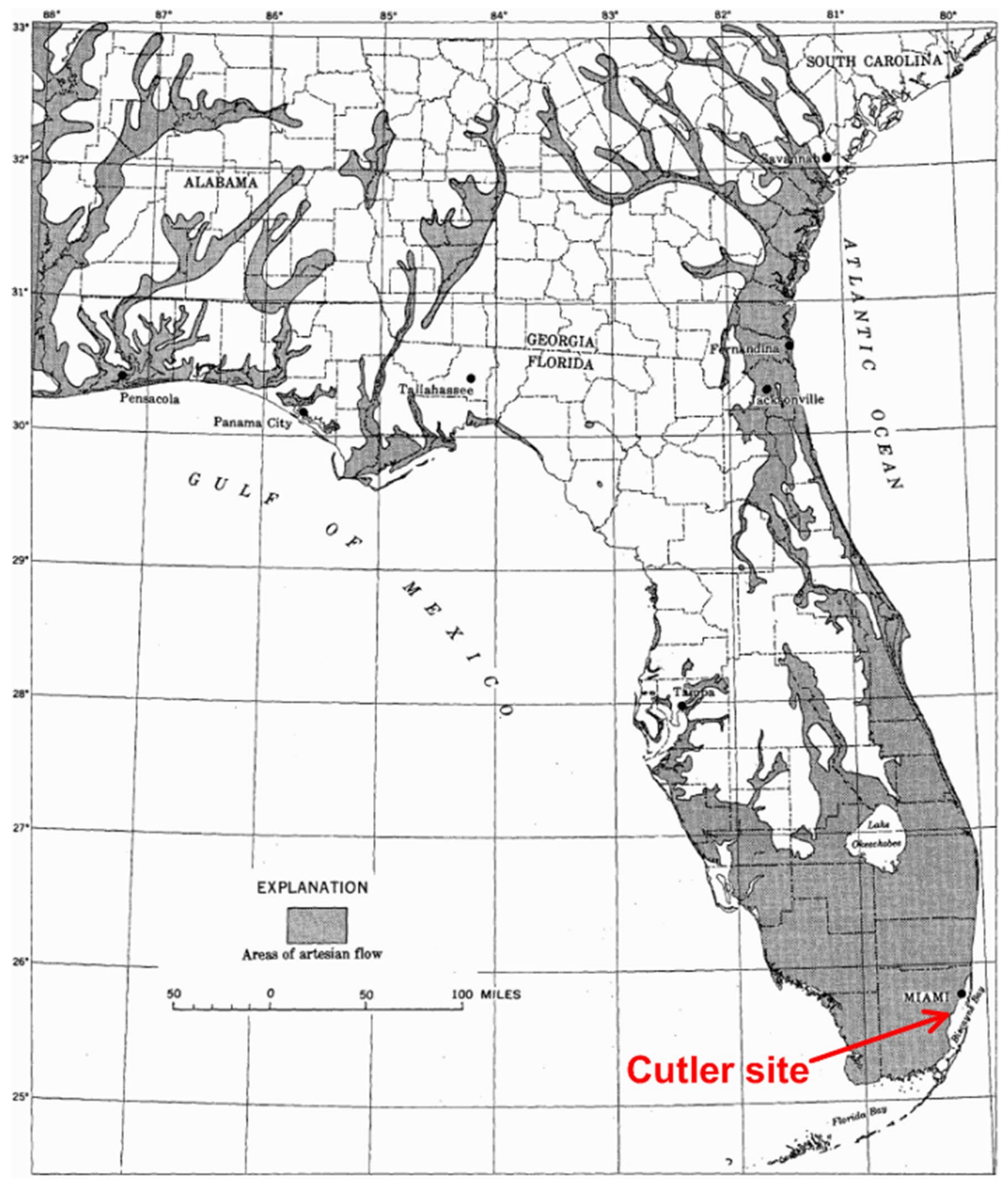

Fig. 12 Areas of artesian flow from regional groundwater flow systems (dark). The recharge areas for deep groundwater flow appear white (from Stringfield 1966, Fig. 28). Red arrow marks the position of the Cutler site, Biscayne Bay, near Miami, Fla

conditions. These concepts became an important part of textbooks, scientific literature on variable-density flow, densitydriven flow, free convection and the management of coastal water supplies.

Revisiting the field data of Cooper et al. (1964), in view of groundwater flow systems theory (Tóth 1963; Freeze and Witherspoon 1967), paves the way for a paradigm shift in such that the chemical and hydrodynamic head data have been caused by regional discharge of saline groundwater from a depth of $600 \mathrm{~m}$ or more and not by density-driven convection flow of seawater from Biscayne Bay. Furthermore, as seawater does not enter the aquifer under non-pumping conditions, neither at low nor at high tide, the postulated zone of dispersion and a saltwater wedge do not exist at the coast of Biscayne Bay and, in all 
Fig. 13 Digital elevation model (DEM) of central and south Florida showing trace of cross section displayed in Fig. 14 and position of the Cutler site at the Biscayne Bay. DEM by WDA Consultants Inc., 2016. Data derived from NASA's Shuttle Radar Topography Mission (SRTM) dataset, extracted by the program GlobalMapper into a 764-m grid

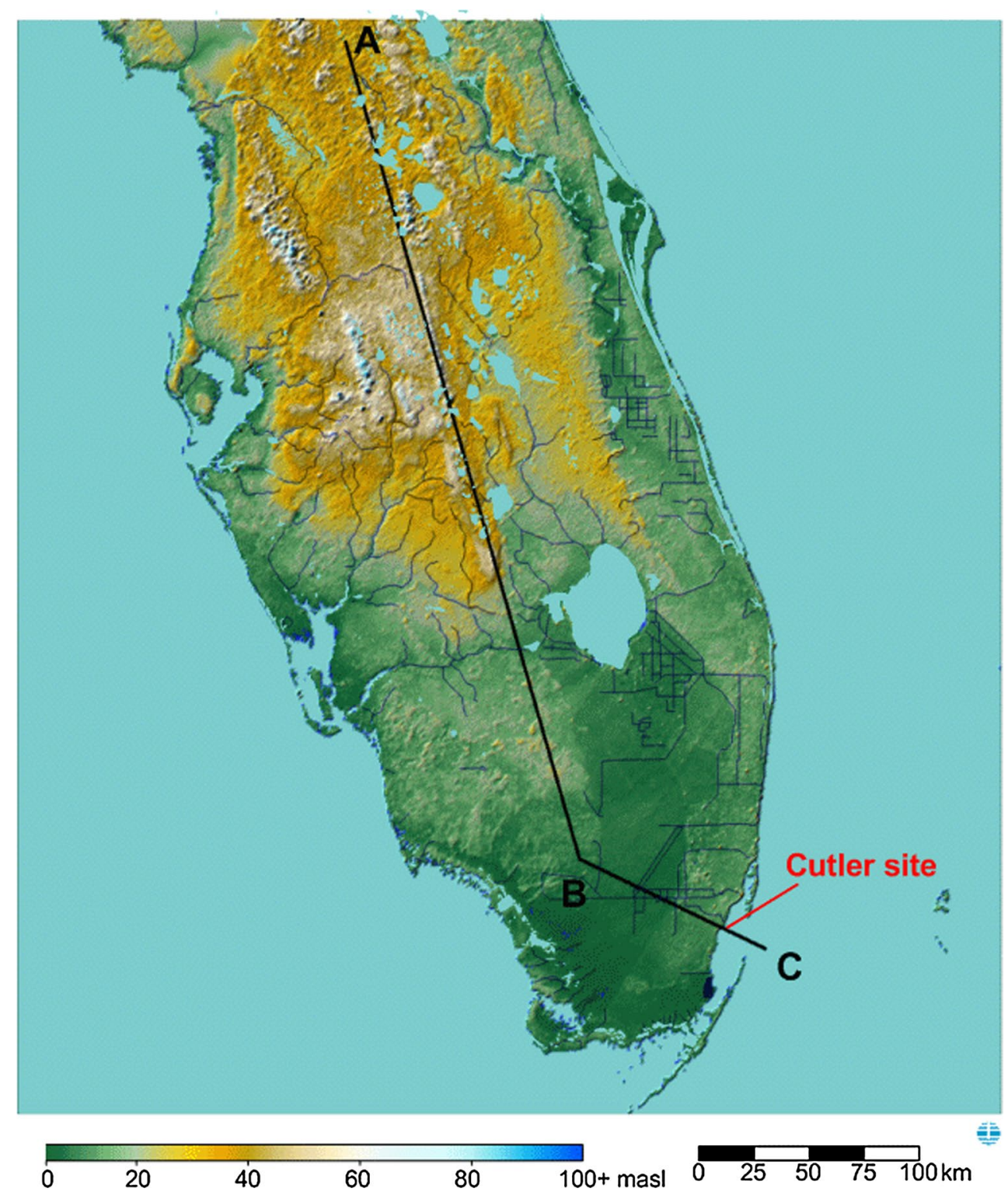

likelihood, also not at the rest of the Floridian coast line and at other coasts with hilly topography worldwide.

In summary, the case of the discharge of deep saline groundwater in the Biscayne Bay area has been proven by five independent methods

- the physics of 'density-driven flow' versus 'groundwater flow systems,'
- the occurrence of artesian (flowing) deep wells throughout South Florida (Fig. 11),

- the penetration depth of fresh groundwater to $600 \mathrm{~m}$ and more indicated by chemical data (Fig. 12),

- the occurrence of the freshwater/saltwater boundary in oil well P115 at approximately $1800 \mathrm{ft}(600 \mathrm{~m})$ about 10 miles $(15 \mathrm{~km}$ ) west of Biscayne Bay (Williams and Kuniansky (2016, plate 19), 

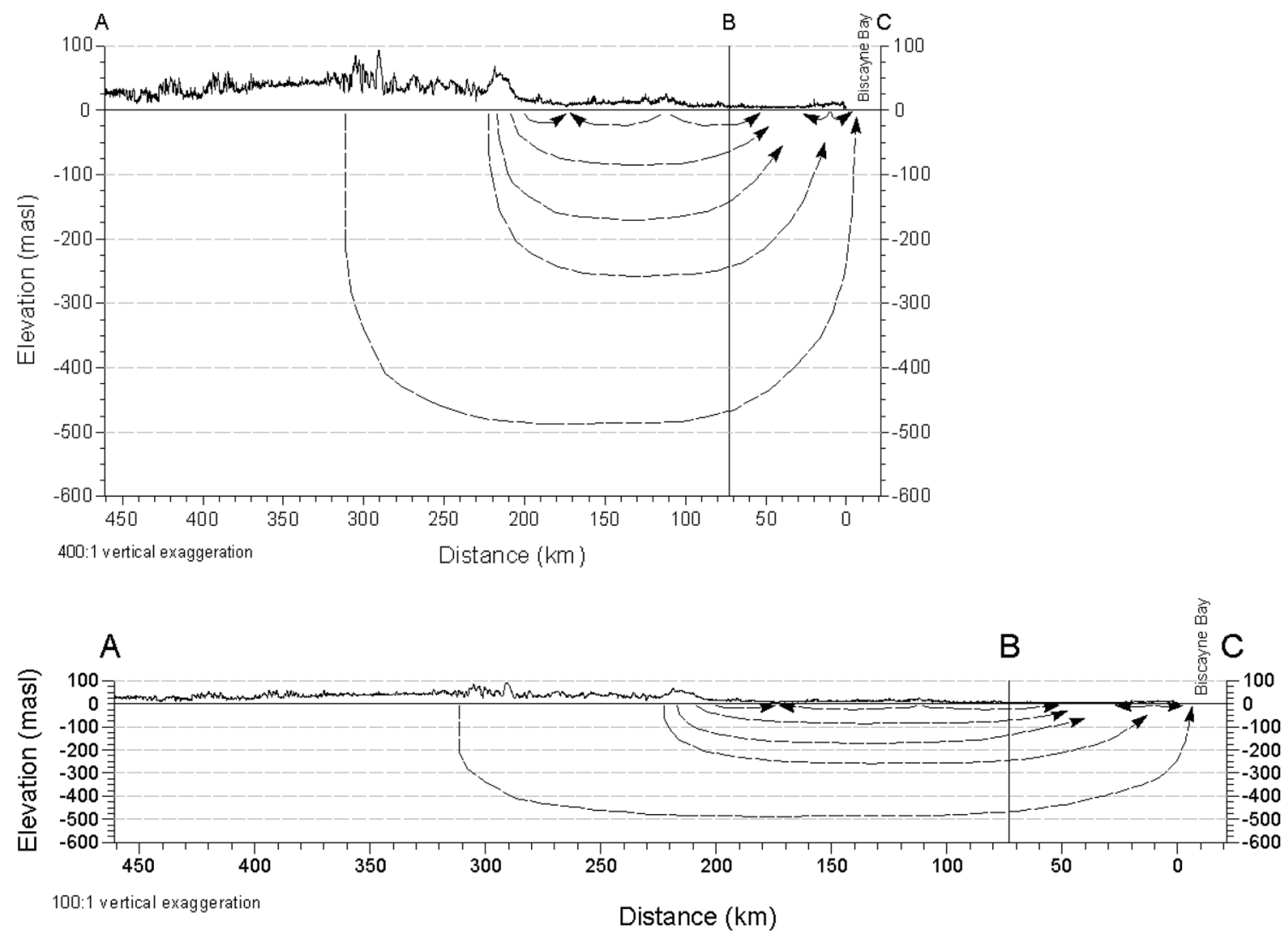

Fig. 14 Cross section of central and south Florida (location in Fig. 13). Very schematic outline of flow lines from the central Florida uplands to Biscayne Bay. Vertical exaggeration 400:1 (left) and 100:1 (below)

- the equal head lines of the equivalent freshwater heads (Figs. 8, 9) as presented by Cooper et al. 1964 (Fig. 16, 17).

Of course, seawater may penetrate coastal aquifers once significant pumping has commenced and, due to a change of the pattern of groundwater flow systems, it may fill voids created by pumping. For optimal management of water supply, the portion of deep saline groundwater to seawater should be determined by application of numerical simulators capable of dealing with density-dependant buoyancy modifications along the direction of the pressure potential forces as in the right-hand side of Fig. 4.

An outlook on the future development of the understanding and application of variable density flow in research and practice as well as the related need for new computer codes is given by Weyer (2017a).

Acknowledgements This paper is the outcome of decades of scientific curiosity, discussions, research, setbacks, and encouragements. In this context, thanks are due to Laszló Király (CHYN, Neuchâtel), Claude Louis (BRGM, Orléans-la-Source), József Tóth (Earth Sciences, Edmonton), Peter Gretener (Geosciences, Calgary), Peter Fritz (Helmholtz Centre, UFZ, Leipzig), Robert Farvolden (Earth Sciences, Waterloo), Emil Frind (Earth Sciences, Waterloo), John Molson
(Université Laval, Québec), James Ellis (WDA, Calgary), and Remi Sasseville (Calgary) as well as many more participants in discussions at about 100 presentations I gave over the last 10 years in 20 countries at conferences, universities, major companies, and governmental agencies in the Americas, Europe, Asia, Australia, and in Africa. Vít Klemeš (Ottawa), Environment Canada's head scientist at the time, broke the deadlock for publishing the 1978 paper by establishing, by means of an outside review contract to W. Douglas Baines (Mechanical and Industrial Engineering, Toronto), the physics and mathematics contained to be correct. Short contacts with M. King Hubbert and Maurice A. Biot at the 1977 BRGM conference "Sciences de la Terre et Mesures" were helpful stepping stones, so was a day of in-depth discussions with Mehran Pooladi-Darvish and Hassan Hassanzadee (Chemical and Petroleum Engineering, Calgary). Since 2014 Anastas Alexis (CSPG, Calgary), Jose Joel Carrillo (UNAM, Mexico City), Andrzej Witkowski (University of Silesia, Sosnowiec), and Jeff Meadows (Potash Corp, Saskatoon) organized courses and thereby forced me to organize clearly my thoughts on the "Dynamics of subsurface flow of groundwater, hydrocarbons and sequestered CO2". I would also like to thank EES, its staff, and the reviewers for their scientifically-oriented minds and openness. I dedicate this paper to my daughter, Katja, and my granddaughters Sasha and Simone.

Open Access This article is distributed under the terms of the Creative Commons Attribution 4.0 International License (http://creativecommons.org/licenses/by/4.0/), which permits unrestricted use, distribution, and reproduction in any medium, provided you give appropriate credit to the original author(s) and the source, provide a link to the Creative Commons license, and indicate if changes were made. 


\section{References}

\section{(Note: all of the USGS publications are available for free download. URLs have been provided for each reference.)}

Anderson PF, Mercer JW, White HO (1988) Numerical modelling of salt water intrusion at Hollandale, Florida. Ground Water 26(5):619-630

Bear J (2007a) Hydraulics of ground water. McGraw-Hill, New York (unabridged republication by Dover edition)

Bear J (2007b) Sea water intrusion into coastal aquifers. In: Delleur JW (ed) The handbook of groundwater engineering, 2nd edn. CRC Press, Boca Raton, pp 12-1-12-27

Bear J, Bachmat Y (1990) Introduction to modeling of transport phenomena in porous media. Kluwer Academic Publishers, Berlin, p 553

Bush PW, Johnston RH (1986) Floridan regional aquifer system study. In: Sun RJ (ed) Regional aquifer-system analysis program of the U.S. Geological Survey, Summary of projects, 19741984. USGS Circular 1002, pp. 17-29. URL: https://pubs.usgs. gov/circ/1986/1002/report.pdf

Cooper HH Jr. (1959) A hypothesis concerning the dynamic balance of fresh water and salt water in a coastal aquifer. J Geophys Res 64(4):461-467

Cooper HH Jr., Kohout FA, Henry HH, Glover RE (1964) Sea water in coastal aquifers: relation of salt water to fresh ground water. USGS Water-supply paper 1613-C, p 95. URL: https://pubs. usgs.gov/wsp/1613c/report.pdf

De Wiest RJ (1965) Geohydrology. Wiley, New York, p 366

Domenico PA (1972) Concepts and models in groundwater hydrology. McGraw-Hill Inc, New York, p 406

Feseker T (2007) Numerical studies on saltwater intrusion in a coastal aquifer in northwestern Germany. Hydrogeol J 15:267-279

Fetter CW (1994) Applied hydrogeology, 3rd edn. Prentice Hall, Upper Saddle River, p 669

Freeze AR, Cherry JA (1979) Groundwater. Prentice-Hall Inc, Englewood Cliffs, p 604

Freeze AR, Witherspoon PA (1967) Theoretical analysis of regional groundwater flow: 2. Effect of water table configuration and subsurface permeability variation. Water Resour Res 4(3):581590. https://doi.org/10.1029/WR003i002p00623

Glover RE (1959) The pattern of fresh water flow in a coastal aquifer in a coastal aquifer. J Geophys Res 64(4):457-459

Guo W, Langevin CD (2002) User's guide to SEAWAT: a computer program for simulation of three-dimensional variable-density ground-water flow. USGS water-resources investigations 06-A7, p 77. URL: https://pubs.er.usgs.gov/publication/twri06A7

Healy HG (1962a) Piezometric surface and areas of artesian flow of the Floridan aquifer in Florida, July 6-17, 1961. Florida geological survey map series 4

Healy HG (1962b) Water levels in artesian and non-artesian aquifers of Florida in 1960. Florida geological survey information circular 33

Henry HR (1959) Salt intrusion into fresh-water aquifers. J Geophys Res 64(11):1911-1919

Henry HR (1960a) Salt intrusion into coastal aquifers. Ph.D. dissertation, Columbia University, New York

Henry HR (1960b) Salt intrusion into coastal aquifers. Int Assoc Sci Hydrol Comm Subterr Waters Publ 52:478-487

Henry HR (1962) Transitory movements of the salt water front in an extensive artesian aquifer. USGS professional paper 450-B, pp B8-B88. URL: https://pubs.usgs.gov/pp/0450b/report.pdf
Henry HR (1964) Effects of dispersion on salt encroachment in coastal aquifers. In: Cooper HH Jr., Kohout FA, Henry HH, Glover RE (eds) Sea water in coastal aquifers. U.S. geological survey water-supply paper 1613-C, pp C71-C84. URL: https:// pubs.usgs.gov/wsp/1613c/report.pdf

Hubbert MK (1940) The theory of groundwater motion. J Geol 48(8):785-944. Available from http://www.jstor.org/ stable/30057101

Hubbert MK (1953) Entrapment of petroleum under hydrodynamic conditions. Bull Am Assoc Pet Geol 37(8):1954-2026. Available from http://archives.datapages.com/data/bulletns/1953-56/ data/pg/0037/0008/1950/1954.htm

Kohout FA (1960a) Cyclic flow of salt water in the Biscayne aquifer of southeastern Florida. J Geophys Res 65(7):2133-2141

Kohout FA (1960b) Flow pattern of fresh water and salt water in the Biscayne aquifer of the Miami area, Florida. Int Assoc Sci Hydrol Comm Subterr Waters Publ 52:440-448

Kohout FA (1964) The flow of fresh water and salt water in the Biscayne aquifer of the Miami area, Florida. In: Cooper HH Jr., Kohout FA, Henry HH, Glover RE (eds) Sea water in coastal aquifers: relation of salt water to fresh ground water. USGS Watersupply paper 1613-C, pp C12-C3. URL: https://pubs.usgs.gov/ wsp/1613c/report.pdf

Konikow LF, Sanford WE, Campbell PJ (1997) Constant-concentration boundary condition; lessons learned from the HYDOCOIN variable density groundwater benchmark problem. Water Resour Res 13(10):2253-2261

Langevin CD (2001) Simulation of ground-water discharge to Biscayne Bay, Southeastern Florida. USGS water-resources investigations report 00-4251, p 137. URL: https://fl.water.usgs.gov/PDF_files/ wri00_4251_langevin.pdf

Langevin CD, Zygnerski M (2013) Effect of sea-level rise on salt water intrusion near a coastal well field in southeastern Florida. Groundwater 51(5):781-803

Lee CH, Cheng TS (1974) On seawater encroachment in coastal aquifers. Water Resour Res 10(3):1039-1043

Lu C, Werner AD, Simmons CT, Luo J (2015) A correction on coastal heads for groundwater flow models. Groundwater 53(1):164-170

Masterson JP (2004) Simulated interaction between freshwater and saltwater and effects of groundwater pumping and sea-level change, lower Cape Cod aquifer system, lower Cape Cod aquifer system, Massachusetts. USGS scientific investigations report 2005-5014. URL: https://pubs.usgs.gov/sir/2004/5014/pdf/sir200405014.pdf

Masterson JP, Garabedian SP (2007) Effects of sea-level rise on groundwater flow in a coastal aquifer system. Ground Water 45(2):209-217

Merritt ML (1996) Assessment of saltwater intrusion in southern coastal Broward County, Florida. USGS water-resources investigations report 96-4221. URL: https://pubs.usgs.gov/ wri/1996/4221/report.pdf

Miller JA (1990) Ground water atlas of the United States, Segment 6: Alabama, Florida, Georgia, South Carolina. Hydrologic investigations Atlas 730-G, USGS Reston Virginia. URL: http://pubs.usgs. gov/ha/730g/report.pdf

Pinder GF, Celia MA (2006) Subsurface hydrology. Wiley, Hoboken, p 468

Pinder GF, Cooper HH Jr (1970) A numerical technique for calculating the transient position of the saltwater front. Water Resour Res 6(3):875-882

Rao SVN, Sreenivasulu V, Bhallamudi SM, Thandaveswarw BS, Sudheer KP (2004) Planning groundwater development in coastal aquifers. Hydrol Sci J 49(1):155-170

Rozell DJ, Wong TF (2010) Effects of climate change on groundwater resources at Shelter Island, New York State, USA. Hydrogeol J 18(7):1657-1665 
Schwartz FW, Zhang H (2004) Fundamentals of ground water. Wiley, Hoboken, p 583

Segol G, Pinder GF (1976) Transient simulation of salt water intrusion in south eastern Florida. Water Resour Res 12:65-70

Shoemaker WB (2004) Important observations and parameters for a salt-water intrusion model. Ground Water 42(6):829-840

Simmons CT, Narayan KA, Wooding RA (1999) On a test-case for density-dependant groundwater flow and solute transport models: the salt lake problem. Water Resour Res 35(12):3607-3620

Spechler RM (1994) Saltwater intrusion and quality of water in the Floridan aquifer system, Northeastern Florida. USGS waterresources investigations report 92-4174, p 78. URL: https:// fl.water.usgs.gov/PDF_files/wri92_4174_spechler.pdf

Stringfield VT (1966) Artesian water in Tertiary limestone in the southeastern states. USGS professional paper 517. URL: https://pubs. usgs.gov/pp/0517/report.pdf

Todd DK, Mays LW (2005) Groundwater hydrology, 3rd edn. Wiley, Hoboken, p 636

Tóth J (1963) A theoretical analysis of groundwater flow in small drainage basins. J Geophys Res 68(16):4795-4812. https://doi. org/10.1029/JZ068i016p04795

Voss CI, Provost AM (2010) Sutra: a model for saturated-unsaturated variable-density ground-water flow with solute or energy transport. USGS water-resources investigations report 02-4231. Version of September 22, 2010 (SUTRA version 2.2), p 300. URL: https://water.usgs.gov/nrp/gwsoftware/sutra/SUTRA_2_2-documentation.pdf

Voss CI, Souza WR (1987) Variable density flow and solute transport simulation of regional aquifers containing a narrow freshwatersaltwater transition zone. Water Resour Res 23(10):1851-1866

Walton WC (1970) Groundwater resource evaluation. McGraw-Hill Book Company, New York, p 664
Werner AD, Simmons CT (2009) Impact of sea-level rise on sea water intrusion in coastal aquifers. Ground Water 47(2):197-204

Werner AD, Ward JD, Morgan LK, Simmons CT, Robinson NI, Teubner MD (2012) Vulnerability indicators of sea water intrusion. Ground Water 50(1):48-58

Weyer KU (1978) Hydraulic forces in permeable media. Mémoires du B.R.G.M., vol 91, pp 285-297, Orléans, France. Available online at http://wda-consultants.com/fn1-hydraulic_forces.htm

Weyer KU (2010) Physical processes in geological carbon storage: an introduction with four basic posters. Internet publication, March 2010, p 47. Available online at http://wda-consultants.com/physicalprocesses.htm

Weyer KU (2017a) 'Frog in a Well' or a pending paradigm shift in hydrogeology? Grundwasser, pp 63-64. https://doi.org/10.1007/ s00767-016-0350-z. http://rdcu.be/oOid

Weyer KU (2017b) Revisiting the Henry problem of 'density-driven' groundwater flow: a review of historic Biscayne aquifer data. IAH symposium on regional groundwater flow, Calgary, AB, Canada, June 27, 2017. Available from http://www.wda-consultants.com/ iah-calgary-2017.htm

Wikipedia (2009) Map of North America, orthographic projection. Map author: 'Bosonic dressing', June 21, 2009. Retrieved from https://en.wikipedia.org/wiki/File:Location_North_America.svg on November 25, 2017 under the creative commons attributionshare alike 3.0 unported license

Williams LJ, Kuniansky EL (2016) Revised hydrogeologic framework of the Floridan aquifer system in Florida and parts of Georgia, Alabama, and South Carolina. USGS professional paper 1807 version 1.1. URL: https://pubs.usgs.gov/pp/1807/pdf/pp1807.pdf 